\title{
Residual Feed Intake towards Efficient Animal Production: A Paradigm Shift?
}

\section{M.S. Mahesh*}

Dairy Cattle Nutrition Division, ICAR-National Dairy Research Institute (Deemed University) Karnal, Haryana, India

Modern methods of selection have contributed greatly to the genetically superior high yielding animals of current animal production systems [1]. While this being the case of the developed world, animal production in the tropics is constrained by the everlasting deficit in feed supply [2]. Therefore, a method based on lower feed intake without affecting mature weight and production will have a greater implication in agri-food industry. This was initially conceptualized in 1963 by Koch et al. [3], who introduced Residual Feed Intake (RFI), and defined it as the difference between actual intake and the expected requirements of feed for maintenance and body weight gain, in beef cattle. Assumption behind using RFI as a selection tool is that the biological processes regulating feed consumption and efficiency are similar in younger and older animals (as there exist high genetic correlation between postweaning intake and maturity) [4]. RFI is a moderately heritable trait in cattle $\left(h^{2}=0.25-0.48\right)$ which is independent of body size and production [5]. One approach for measuring RFI is by recording individual animal data on intake and growth for a minimum period of 35 days [5], while the second is by pre-screening for blood metabolites such as insulin like growth factor-1 followed by selection through RFI for increasing growth rate, feed efficiency and proportion of lean meat [4]. Expected dietary intake is estimated by means of a multiple regression equation of consumption, as determined by the metabolic live weight and weight gain $[4,6]$.

Animals differing in RFI (i.e., low vs. high) differ in their efficiency for utilizing nutrients for maintenance and production, and those with low or negative RFI are most efficient [6]. Physiological basis for such varied efficiency has been ascribed to a range of factors including intake, digestion and metabolism of feed, physical activity, thermoregulation, synthesis and breakdown of proteins, genes encoding different biochemical processes, gene expression of gut microorganisms and hypothalamus, reticulo-rumen functions and mitochondrial respiration rate etc. [7-9]. Furthermore, RFI did not adversely influence blood metabolites in beef cattle [10] and Sahiwal calves [6], while maintaining optimum growth rate. Though majority of RFI studies have focused on beef cattle, it is plausible that the efficient dairy cows be identified based on RFI [11]. Expected intake of cows can be determined by regressing intake on metabolic body weight, change in body weight and energy corrected milk yield. Efficient cows in RFI test exhibited decreased feed/energy intake, slower rate of consumption and its flow rate leading to an improved nutrient digestibility [11] with the simultaneous reduction in manure nutrient losses [5].

One of the potential environmental benefits demonstrated in low RFI cattle is the decreased methane $\left(\mathrm{CH}_{4}\right)$ emission, which was noted in temperate [12] as well as tropical regions [6]. Factors like lower maintenance requirement and thus lower dry matter intake, reduced ruminal retention of feed, higher ruminal fermentation rate [5] and a changes in methanogen genotype abundance [13], altogether favorably decreasing methanogenesis. As $\mathrm{CH}_{4}$ production is positively correlated with RFI and has low to moderate heritability and repeatability, it is possible to select and breed cattle for low $\mathrm{CH}_{4}$ emission for environment friendly livestock production [5].
As livestock are largely considered to be unsustainable [14], considering RFI in selection process, may offer scope for sustainability, as efficient animals will have economic growth and milk production with minimum $\mathrm{CH}_{4}$ emission. Furthermore, it is advised to improve animal productivity rather than maintaining large unproductive herds [2]. In this direction, as RFI selects animals for higher efficiency, it's possible to maintain a low number of efficient stocks in the herd requiring low inputs, whilst minimizing carbon foot print of cattle enterprises.

\section{References}

1. De Mello F, Kern EL, Bertoli CD (2014) Progress in dairy cattle selection. Adv Dairy Res 2: 110.

2. Oosting SJ, Udo HMJ, Viets TC (2014) Development of livestock production in the tropics: farm and farmers' perspectives. Animal 8: 1238-1248.

3. Koch RM, Swiger LA, Chambers D, Gregory KE (1963) Efficiency of feed use in beef cattle. J Anim Sci 22: 486-494.

4. Bezerra LR, Sarmento JLR, Neto SG, de Paula NRO, Oliveira RL, et al. (2013) Residual feed intake: a nutritional tool for genetic improvement. Trop Anim Health Prod 45: 1649-1661.

5. Basarab JA, Beauchemin KA, Baron VS, Ominski KH, Guan LL, et al. (2013) Reducing GHG emissions through genetic improvement for feed efficiency: effects on economically important traits and enteric methane production. Animal 7: 303-315.

6. Sharma VC, Mahesh MS, Mohini M, Datt C, Nampoothiri VM (2014) Nutrient utilisation and methane emissions in Sahiwal calves differing in residual feed intake. Arch Anim Nutr 68: 345-357

7. Hendriks J, Scholtz MM, Neser FWC (2013) Possible reasons for differences in residual feed intake: An overview. South Afr J Anim Sci 43: s103-s106.

8. Fitzsimons C, Kenny DA, McGee M (2014) Visceral organ weights, digestion and carcass characteristics of beef bulls differing in residual feed intake offered a high concentrate diet. Animal 8: 949-959.

9. Perkins SD, Key CN, Garrett CF, Foradori CD, Bratcher CL, et al. (2014) Residual feed intake studies in Angus-sired cattle reveal a potential role for hypothalamic gene expression in regulating feed efficiency. J Anim Sci 92: 549560 .

10. Santana MHA, Rossi Junior P, Almeida R, Schuntzemberger AMS (2014) Blood cell and metabolic profile of Nellore bulls and their correlations with residual feed intake and feed conversion ratio. Rev Bras Saúde Prod Anim Salvador 14: 527-537.

11. Connor EE, Hutchison JL, Olson KM, Norman HD (2012) Opportunities for improving milk production efficiency in dairy cattle. J Anim Sci 90: 1687-1694.

*Corresponding author: M.S. Mahesh, Dairy Cattle Nutrition Division, ICARNational Dairy Research Institute (Deemed University) Karnal, Haryana, India, Tel: +919541853329; E-mail: drmaheshmsvet@gmail.com

Received December 25, 2014; Accepted December 29, 2014; Published December 30, 2014

Citation: Mahesh MS (2015) Residual Feed Intake towards Efficient Animal Production: A Paradigm Shift? J Veterinar Sci Technol 6: e113. doi:10.4172/2157$7579.1000 \mathrm{e} 113$

Copyright: () 2015 Mahesh MS. This is an open-access article distributed under the terms of the Creative Commons Attribution License, which permits unrestricted use, distribution, and reproduction in any medium, provided the original author and source are credited. 
Citation: Mahesh MS (2015) Residual Feed Intake towards Efficient Animal Production: A Paradigm Shift? J Veterinar Sci Technol 6: e113. doi:10.4172/2157-7579.1000e113

Page 2 of 2

12. Nkrumah JD, Okine EK, Mathison GW, Schmid K, Li C, et al. (2006) Relationships of feedlot feed efficiency, performance and feeding behaviour with metabolic rate, methane production, and energy partitioning in beef cattle. J Anim Sci 84: 145-153.

13. Carberry CA, Waters SM, Kenny DA, Creevey CJ (2014) Rumen methanogenic genotypes differ in abundance according to host residual feed intake phenotype and diet type. Appl Environ Microbiol 80: 586-594.

14. Eisler MC, Lee MRF, Tarlton JF, Martin GB, Beddington J, et al. (2014) Agriculture: Steps to sustainable livestock. Nature, 507: 32-34. 